\title{
A Theoretical Evaluation of the Role of Training for Supply Chain Management Employees of the Department of Provincial Treasury: Case of KwaZulu-Natal, South Africa
}

\author{
Sakhile Manyathi \\ Deputy Director: SCM Training, Department of National Treasury \\ Email: Sakhile.Manyathi@treasury.gov.za \\ Ferdinand Niyimbanira \\ Lecturer in Economics, Vaal University of Technology (VUT) \\ Email: ferdinandn@vut.ac.za
}

Doi:10.5901/mjss.2014.v5n7p231

\begin{abstract}
The escalating, inverse, supply chain management (SCM) audit reports, issued to the KwaZulu-Natal Provincial Government Administration by the Auditor-General of South Africa (AGSA), indicate that ground root citizens of the KwaZulu-Natal province are being deprived of community services. The aim of this study is to critically evaluate and review the most theoretical possible root causes of the inverse audit reports, to discover whether inadequate training and compliance enforcement are possible determinants of qualified audit reports. It is recommended that management consider developing a cadre of SCM professionals, by conducting a baseline assessment of human resource capacity for SCM, which identifies supply chain tasks and functions by the level of the supply chain involvement; consider assessing, casting, and detecting human resource gaps, in terms of skills and pool of employees available.
\end{abstract}

Keywords: Training, Supply chain Management, South Africa, employees

\section{Introduction}

The KwaZulu Natal (KZN) Department of Provincial Treasury is the custodian of all supply chain management processes, norms and standards for the province. It regulates all KZN provincial government departments in terms of legislation, prescripts, processes, and procedures regarding SCM. The Provincial Treasury is among the 75percent of departments that did not receive a clean audit for the financial year of 2007/2008. Hence, there is a dire need for this study on provincial administration SCM processes. Even though the Provincial Treasury is the custodian of all SCM processes, the majority of KZN provincial departments have received an escalating number of qualified audit reports. These qualified audit reports affect service delivery to grass root citizens of the KZN province negatively, and raise the question as to why there is either none, or a less significant service delivery to these communities.

Therefore, the main aim of this paper is to evaluate theoretically the supply chain management systems in general and of the KwaZulu Natal Department of Provincial Treasury in particular. Hence, it sought to examine relevant theories regarding the nature of SCM training and the effectiveness of evaluating training programmes. The continuous, qualified and audit queries, received by the provincial administration departments, are a worrying factor in South Africa. Determining the possible root causes of these qualified audits may shed more light on the nature of the challenges and may lead to the formulation of strategic solutions. The budget to these qualified departments constitutes a sizable portion of the provincial government budget and non-compliance to SCM prescripts hinders service delivery, therefore, depriving the very poor and vulnerable communities. Should the audit reports not be followed-up correctly, it could result in some provincial departments, if not the whole province, being put under the administration of the National Treasury (NT). This happened to the Limpopo Provincial Government, when the NT too it over due to maladministration as per section 100(1) of the Constitution of the Republic of South Africa (108 of 1996). 


\section{Concepts and Theories Relating to Employees' SCM Learning and Training}

In this context, attempts are made to review literature related to understanding the importance of learning, SCM training, and development in government departments. It explores theories of learning, training and development, and training evaluation, as well as individual and organisational benefits of training. An examination is also made of the different types of training methods and their appropriate application. The review examines organisational commitment as a factor of work-related attitude, and training as an instrument, which has an impact on individual effectiveness (Ahmad and Bakar 2003). Theories relating to employees' perception of training are also examined, as are employee performance measurement, and the monitoring of annual performance plans (APP). This chapter also compares training programmes within the public procurement sector in South Africa. It explores arguments for the principles of public auditing, as well as compliance enforcement measures.

The study of public administration in South Africa has its formation and foundation in Chapter 10 of the RSAs Constitution (108 of 1996). The efficient, economic and effective use of scarce resources is a paramount requirement for the provision of satisfactory service delivery (Schwella, et al., 1996: 6) defines resource management as the organisation of basic, administrative support systems, for example budgeting, fiscal management, procurement and supply, and human resource management. More specifically, from a public management viewpoint, public resource management aims to manage resources allocated by politically legitimate means to public institutions, in the most efficient and effective way. It seeks to attain the policy goals and objectives of constitutional, government structures. Therefore, the effective, efficient, and productive management of public resources is subject to political, economic and social imperatives, as constitutionally reflected above (Schwella, et al. 1996:3). All this is, however, not practical without a fully skilled and trained workforce, especially that of supply chain management officials, as they are at the tip of service delivery in South Africa.

SCM is defined as "the integration of key business processes, from end user through original suppliers that provides products, services, and information that add value for customers and other stakeholders" (Cooper, Lambert et al. 1997:133). SCM ideally embraces all business processes, cutting across all organisations within the supply chain, from initial point of supply, to the ultimate point of consumption. According to (Cooper, Lambert et al. 1997:145), SCM embraces the business processes identified by the International Centre for Competitive Excellence (now Global Supply Chain Forum). Accordingly, electronic-SCM (e-SCM) is defined as the impact the Internet has on the integration of key business processes. This is applicable to the purchaser, as well as the initial suppliers, who make products, services, and information available that add value for consumers and other interested parties. The Internet can have three main impacts on the supply chain. One of the most covered topics in the literature is the impact of e-commerce, which refers mainly to how companies can respond to the challenges posed by the Internet on the fulfilment of goods sold through the net. Another impact refers to that of information sharing, and how the Internet can be used as a medium to access and transmit information among supply chain partners. However, the Internet not only enables supply chain partners to access and share information, but also to access data analysis and modelling, to enable better, joint planning and decision-making. This joint planning and decision-making is the third type of impact of the Internet on SCM, and is referred to as knowledge sharing.

\subsection{Training}

Training is the process of enhancing the skills, capabilities, and knowledge of employees for doing a particular job. The thinking of employees is moulded by the training process, which leads to quality performance of employees. It is a continuous and a never-ending process in nature, (Adamolekun1983:96).The Public Administration Leadership and Management Academy (PALAMA), as the government training department, provides capacity-building interventions, aimed at developing a public service cadre who cares, belongs, serves, and delivers in a manner that is developmental. As the capacity-building vehicle of government, PALAMA manages and offers training and development opportunities to public servants at national, provincial, and local spheres of government, as well as to various state-owned companies (SOCs). PALAMA has also expanded its reach to support legislature and parliament, with the design and delivery of training in governance, leadership, and management (Ringquist, 2013:238).Merilee (1997:49) states that the quality of employees and their development through training and education are major factors in determining long-term sustainability of service delivery. When hiring and keeping good employees, it is good policy to invest in the development of skills, to increase productivity within the public sector, especially in supply chain management.

Often, training is considered to be only for new employees. This is a mistake, because on-going training of current employees assists with their adjustment to rapidly changing SCM job requirements. Government owes its existence 
primarily to the people it serves and its fundamental purpose, as an institution, is to enhance the general welfare of communities. The various organs of state should therefore coalesce to produce administrative processes that ensure the provision of quality and timely services. These services are needs driven; thus, there is an important connection between the level of development of a particular community and the need for services rendered by government through public administration (Du Toit and Van der Walt 1997:23). To understand the term public administration, an elaboration on the word 'administration' is required. To administer means to manage the affairs of; therefore, administration refers to spheres of human activity being managed through co-operation and consensus, with the aim of reaching or attaining an objective. This also includes the methodology, means, and processes of how this is to be achieved. When the adjective, public, is added to administration, it refers to those functions or phenomena being practised in a political environment, aimed at satisfying societal needs, as perceived in a specific period (Thornhill and VanDijk, 2010: 101). Public administration is a feature of all nations, whatever their system of government, as it is both an activity and a discipline.

\subsection{Reinforcement Theory}

The reinforcement theory suggests that trainers and supervisors can best enhance learning and transfer of knowledge and skills by identifying what rewards or outcomes the learner finds most positive (Goldstein and Ford 2002). Training specialists can increase trainees' self-efficacy by using behavioural modelling and by providing words of encouragement. Noe et al. (2008) note that trainees' self-efficacy levels can also be increased by providing as much information as possible about the training programme and the purpose of training before training begins, while reducing perceived threats to trainees by emphasizing performance outcomes initially, which become more important after training. In addition, showing employees the training successes of peers in similar jobs, and helping trainees to develop better strategies to use during training, such as summarising main points and using memory, aids to help retention.

\subsection{Behavioural Theory}

Behaviourism focuses on objectively, observable behaviours and discounts mental activities. Behaviourists focus on eliminating maladaptive, conditional reflexes and developing more adaptive ones, often working with people suffering from irrational fears or phobias (Alberto and Troutman 2003). The authors view learning as the acquisition of new behaviour. As a universal learning process, two different types of conditioning are identified:

i) Classical conditioning: This is a process of learning by association in which two events that repeatedly occur close together in time become fused in a person's mind and produce the same response (Comer 2004; Chowdhury, 2006). This means that learning occurs when a natural reflex responds to a stimulus.

ii) Operant conditioning: This is when changes in behaviour are the result of an individual's response to events (stimuli) that occur in the environment (Skinner 1968). Skinner (1968) expounds that voluntary or automatic behaviour is either strengthened or weakened by the immediate presence of a reward or punishment. Mankin (2009:112) describes behavioural learning theory outcomes to be the result of a learning process. Learning is a relatively permanent change in behaviour that occurs because of practice or experience.

\subsection{Cognitive Theory}

Chowdhury (2006:2) treats motivation as a crucial aspect of the learning process. He contends that it is related closely to arousal, attention, anxiety, and feedback or reinforcement. The point that assumes importance in the context of training and development, according to Chowdhury (2006:3), is individual behaviour, which is goal directed. Therefore, training should consider the trainee's goal. Learning is a meaningful process; therefore, training must evolve as a process where the learner can understand what he learns, and each learner learns through his own cognitive map. A cognitive map is a mental representation of the layout of one's environment (Mankin, 2009:96). Individuals learn by interacting with their environment or by the observation of other individuals interacting with similar environments. Learning occurs as an individual's actions lead to environmental responses, which are interpreted by individuals who share their interpretations, based on cause-effect relationships. The trainer should take this into account and organise a programme, based on learners' cognitive maps. Mankin (2009:115) asserts that cognitive learning theory can be determined as a "qualitative change in a person's way of seeing, experiencing, understanding, and conceptualizing something in the real world." This involves the process of information inside the individual's mind. 


\subsection{Sociological Learning Theories}

Social learning theory introduces the concept of a role model, suggesting that individuals will seek to model themselves on others, who they perceive to be successful. In the context of training, learners learn by practicing the required behaviour in the group. In the context of training, learners practice learning and participating, and the group context are connected, they cannot be isolated from each other. This means that the learning that takes place by each participant affects the whole group (Coetzeeet al. 2007:59-60).Situated learning or, as it is often termed, social cognitive theory, is a variation on social learning and is about developing an individual's competence. Discussions with colleagues, mentors, and specialist experts, usually within the same community or social network, are a typical example of this type of learning in a work context (Mankin 2009:123).

\section{Employee Perception of Training: Its Influences}

As much as attitude affects an individual's behaviour in the workplace, so does perception. Perception is defined as "a process by which individuals organise and interpret their sensory impressions in order to give meaning to their environment" (Langton and Robbins 2007:126). Moreover, perceptions can and do vary from person to person, which can cause great differences in a workplace environment. This section examines employees' motivation and perceptions about the training and workplace environment, and the perceived benefits of training to the individual and the organisation. The section also explores the various perception and motivation theories on training, and its effect on organisational commitment.

Cheng and Hampson (2008:330) strongly recommend more investigating on the decision role of trainees in the transfer process. They argue that trainees play an important role in transfer, and are the agents who decide whether to transfer or not to transfer, and even how much of the knowledge gained they want to transfer. Noe, Colquitt and Lepine (2008:675) find that research must examine how personal characteristics relate to training effectiveness, while Pugh and Bergin (2006:150) argue that trainees' motivation has a significant impact on transfer because of their influence on cognitive engagement, which in turn influences the transfer of training. This is understood as the willingness of a learner to learn the content of a training programme (Cloete1981:124). It is a trainee's intrinsic or extrinsic desire to achieve a high degree of learning. Researchers have concluded that motivation to learn influences either trainee's training performance or transfer outcome (Cheng and Ho 2001; Pugh and Bergin 2006:150).

This can be described as the trainee's desire to use the knowledge and skills that have been learned in a training programme, 'on the job', (Axtell and Maitlis 1997:201). Trainees' motivation to transfer is a key variable in determining the level of transfer of training, since in order to transfer new learned knowledge and skills to the workplace, trainees must also first be committed to using what they have learnt (Axtell and Maitlis 1997:201-2). Kontoghiorghes (2004:114) concludes that the higher the motivation to transfer, the more the transfer will occur. More recently, Liebermann and Hoffmann (2008:75) examined the relationship between transfer motivation and transfer effects in a German bank, and results showed a positive research that addresses the relationship between motivation to transfer and the transfer of learning.

Intrinsic motivation is defined as the confidence of an individual in their competency to perform a specific task (Bandura 1982). According (Cloete, 1981:169), if employees lack intrinsic motivation, then transfer of training cannot be successful. Therefore, self-efficacy is described as a powerful motivational predictor of transfer. This is also called achievement goal orientation or goal orientation, and refers to the pattern of cognition and action those results from the trainee's attempts to attain learning outcomes (Cloete, 1981:186). Two qualitatively different types of goals have been recognised; mastery goals and performance goals. According to Pugh and Bergin (2006:151), a mastery goal emphasises developing skills and gaining competence, while a performance goal emphasises appearing competent. Mastery goals can be bisected to mastery-approach and mastery-avoidance goals, in which the mastery approach focuses on attaining positive learning results ("I want to learn as much as possible from this course"), whereas the mastery-avoidance goal avoids negative learning results ("I worry that I may not learn all that I possibly could in this course"), (Pintrich, 2000:94).Similarly, a performance-approach focuses on appearing competent ("It is important for me to do better than other students"), and performance-avoidance focuses on avoiding appearing incompetent ("my goal in this course is to avoid performing poorly") (Coutinho \& Neuman, 2008:133).

In exchange for displayed organisational commitment, employees expect to be provided with training and development opportunities as part of their unwritten psychological contract with the organisation (Bartlett 2001:236). Literature also suggests that positive, work-related behaviour and attitudes largely depend on employee perceptions as to the extent to which their employer values their contribution and cares about their well-being (Wright et al. 2003). Social 
exchange is initiated by organisations when they signal their willingness to cater for employee interests (Williams 2007:1630). Employees reciprocate with positive attitudinal and behavioural responses that are helpful to their organisation (Settoon, Bennett \& Liden, 1996:220; Aryee, Budhwar \& Chen, 2002:269). Research suggests that training and development provision is taken as a sign by employees that the organisation desires to enter into a social exchange with them. This creates a strong psychological bond between them and their employer (Garrow, 2004:8).

\subsection{Importance of training}

Training is crucial for organisational development and success. It is fruitful to both employers and employees of an organisation. An employee will become more efficient and productive if he is trained well (Merilee, 1997:67). Training is provided on four basic grounds:

- New candidates who join an organisation are given training. This training familiarises them with the organisational mission, vision, rules and regulations, and the working conditions.

- Existing employees are trained to refresh and enhance their knowledge.

- If any updates and amendments take place in technology, training is given to cope with those changes, for instance purchasing new equipment, changes in technique of production, or computer implementation. Employees are trained on the use of new equipments and work methods.

- When promotion and career growth becomes important, training is given so that employees are prepared to share the responsibilities of the higher-level job.

Merilee (1997:105) summarises the benefits of training as follows:

- Training helps the employee to get job security and job satisfaction. The more satisfied the employee is and the greater is his morale, the more he will contribute to organisational success and the lesser will be employee absenteeism and turnover. A well-trained employee will be well acquainted with the job and will need less supervision. Thus, there will be less wastage of time and efforts.

- Employees acquire skills and efficiency during training. They become more eligible for promotion and an asset for the organisation. Training improves efficiency and productivity of employees. Well-trained employees show both quantity and quality performance. There is less wastage of time, money and resources if employees are trained properly. Errors are likely to occur if the employees lack knowledge and skills required for doing a particular job. The more trained an employee is, the less the chances of committing accidents on job and the more proficient the employee becomes.

\section{Methods of Training}

According to Merilee (1997:235), generally training is imparted in two ways: firstly, on job training are given to the employees within the everyday working of a concern. It is a simple and cost-effective training method. The non-proficient, as well as semi-proficient employees can be well trained by using such a training method. Employees are trained in an actual working scenario. The motto of such training is 'learning by doing'. Instances of such on-the-job training methods are job-rotation, coaching, and temporary promotions. Secondary off-the-job training methods are those in which training is provided away from the actual working environment and generally are used in the case of new employees. Workshops, seminars and conferences are examples of off-the-job training methods. Such methods are costly and effective if, and only if, a large number of employees have to be trained within a short time period. Off-the-job training is also known as vestibule training-employees are trained in a separate area (this may be a hall, entrance, or reception area known as a vestibule) where actual working conditions are duplicated.

\subsection{Approaches to the Evaluation of Training}

Birdi (2010:1) proposed a training evaluation model, Taxonomy of Training and Development Outcomes (TOTADO), which attempts to give a broader perspective on types of outcomes beyond individual learning of knowledge and skills, work evaluation approaches, such as changing employees' status, relationship to colleagues or even health. In Kirkpatrick's (1979) model of evaluation of training, the last level (results evaluation), appraises the training's impact on the organisation. The weakness with the model, which Kirkpatrick (1979:89) himself acknowledged, is that "there are so many complicating factors that it is extremely difficult, if not impossible, to evaluate certain kinds of programmes in terms of results". The model has been used mainly to consider individual level analysis, from level one to three. The outcomes 
would therefore refer predominantly to the individual, whereas the other levels of outcome are equally important. In the TOTADO framework, outcomes can be measured at four basic levels, namely at individual, team or workgroup, organisational, and societal levels (Appendix A).

\subsection{Individual Learning Outcomes}

These assess the participant's reaction to training, motivation, self-efficacy, attitudes, and mental wellbeing. It also measures cognitive abilities, such as verbal knowledge and knowledge presentation. In addition, physical health, fitness, and injuries are considered. These are instrumental outcomes, resulting from participation in training and development activities that are work intrinsic (increased job control), work extrinsic (pay rise, promotion), or work relational (forming new relationships or networks).

\subsection{Team Level Outcomes}

Birdi (2010:3) argues that with the increasing implementation of teamwork in the workplace there has been a concurrent rise in team training and development activities. This impacts on four dimensions, which are:

- The affective, for example changes in team identity or trust

- The cognitive, for example verbal knowledge or knowledge presentation in terms of shared cognition

- Behavioural, such as team tasks, processes, intra-team processes

- Instrumental, for example events, actions, or status changes for the team as a whole, such as team bonuses.

\subsection{Organisational Level Outcomes}

This is the domain that Kirkpatrick (1959) refers to as level four or business results. Richard et al. (2009:720) argue that Kirkpatrick (1959) remains vague in terms of what aspects should be considered in this level, and they specify the four dimensions of organisational performance outcomes as:

- Financial, such as turnover, profit, and share price

- Outputs, such as quantity, quality, and a variety of components, products or services

- Processes - how well the organisation functions, such as communication system efficiency

- Resources - both human and non-human.

\subsection{Societal Level Outcomes}

These relate to the impact of training beyond the organisational level, where the area or group outside the organisation is the unit of analysis. Wright et al. (2005:412) contend that organisational researchers go beyond individual and team levels and relate the amount of training offered by companies to goal-directed outcomes such as sales or turnover. The framework should, therefore, be flexible enough to cater for a wide variety of concepts where learning effectiveness is to be assessed. Brum (2005:7) asserts that it is worthwhile for companies to measure why training may lead to reduced turnover rates such as increasing employee commitment, increasing loyalty by providing a 'gift', increasing identification with the organisation, and providing that which primarily permits them to improve performance with the department but not necessarily outside the organisation.

\section{Effects of Training and Development on Employee Attitude and Compliance to SCM Legislation}

Several authors have suggested that training is most extensive only in establishments, which operate in complex market environments (Rowden and Conine 2005:217; Sahinidis and Bouris 2008). In addition, Rowden and Conine (2005:218) indicate that there is limited research on human resource development in small and medium sized businesses. According to these authors, most people believe that small businesses do little, if any, development of their workers. Moreover, Rowden and Conine (2005:218) cite Training Magazine, which annually conducts research on the training industry in the United States, as not attempting even to contact businesses with fewer than 100 employees. Their research endeavours to locate objective evidence in support of connecting training and attitude, its impact on job proficiencies, and the employee's perception that lack of meaningful training directly affects proficiencies. Cheng and Ho (2001:20) also highlight the importance of training and its impact on job performance. They argue that while employee performance is 
one of the crucial measures emphasised by top management, employees are more concerned about their own productivity, and are increasingly aware of the accelerated obsolescence of knowledge and skills in their turbulent environment. The authors conclude that by effectively training and developing employees they will become more aligned for carrier growth, and with such carrier potential, their personal motivation is enhanced.

According to studies by Bartlett (2001:236), Ahmad and Bakar (2003:167), and Al-Emadi and Marquardt (2007) there is a strong positive relationship between training perceptions and affective organisational commitment, and a weaker relationship with continuance commitment. Al-Emadi and Marquardt (2007:50) examine the perceptions of senior staff, in the Qatari petrochemical industry, on the perceived benefits of training participation and its impact on organisational commitment, finding a positive relationship between perceived training benefits and both affective and continuance commitment.

The perceived availability of training is taken to be the extent to which employees feel they are able to access training opportunities (Newman, Thancoody and Hui 2010:5). Research has concluded that employees with positive perceptions of training availability will be more committed to the organisation (Bartlett 2001:236). Bartlett (2001:236) and Ahmad and Bakar (2003:168) suggest that organisations may enhance affective commitment by promoting awareness of training opportunities.

Bartlett (2001:238) demonstrates a significant relationship between supervisor support for training and both affective and continuance commitment. These findings illustrate the potential benefits that may be gained from the creation of an environment in which participation in training and development activities is encouraged by supervisors. Supervisors play a vital role in cultivating subordinate commitment (Cheng, Jiang and Riley 2003:24). Such personal attachment to a supervisor results from a prescribed social norm, dictating a requirement to be loyal to those with seniority (Wang 2008:918).

The impact of the relationship between co-workers on organisational performance has received less attention than the relationships between supervisors and their subordinates (Wang 2008). Perceived co-worker support for training has been shown to have a positive impact on participation rates and affective commitment (Bartlett 2001:337). This illustrates the potential benefits brought to organisations, creating a culture in which co-workers support each other's participation in training.

Ahmad and Bakar (2003:168) suggest that employees who recognise the benefits of training will tend to be more committed and more willing to participate in an organisation's training activities. Empirical work also confirms such a relationship (Bartlett 2001; Ahmad and Bakar 2003; Al-Emadi and Marquardt 2007:50). Ahmad and Bakar (2003:168) find evidence of a significantly positive relationship between benefits of training and affective and continuance commitment. Bartlett (2001:340) distinguishes between the carrier-related, personal benefits of training, and both affective and continuance commitment. These findings illustrate the potential benefits of enhancing organisational commitment, by promoting personal and carrier-related benefits of participating in training.

Failure to provide training and education by the organisation could result in conflict between employer and employee. Such conflict could potentially lead to a number of scenarios, including but not limited to formal complaints by the employee, which eventually become actual lawsuits against the organisation, all of which could cost the industry time, energy and money (Truitt, 2011:2). It is clearly extremely important that employees benefit from employers providing ongoing training. "One of the most frequently encountered human, capital development interventions is training" (Campbell and Kuncel, 2001:278). To enhance job performance, training skills and behaviours have to be transferred to the workplace, maintained over time, and generalised across contexts (Holton \& Baldwin 2000:2). More specifically, in addition to the exact nature of job training, training is seen as relevant to fostering a positive relationship between learning satisfaction and the effectiveness of applied learning (Liu 2000, 2003:44; Wang 2001:920).

The organisational commitment, or "the relative strength of an individual's identification and involvement in a particular organization" (Pool \& Sewell 2007), depends on effective training and development programmes. According to these authors, organisations demonstrating keen insight make provisions for satisfying the training needs of their current workforce. Cheng and Ho (2001:22) indicate that adequate training produces marked improvements in employee communication and proficiency of performances, as well as extending retention time. Additionally, training and education have been shown to have a significant, positive effect on job involvement, job satisfaction, and organisational commitment (Karia \& Asaari 2006:33).Poor performance reviews, due to inadequate job training, can produce employee dissatisfaction and conflict. Although no direct link exists in the literature between training and job satisfaction, Rowden and Shamsuddin (2000:310) and Rowden and Conine (2005:219) argue that the most thoroughly trained employees will better satisfy the needs of their customers and employees. 


\section{Training and Development Legislation in South Africa}

The Skills Development Act (97 of 1998) provides an institutional framework for the implementation of national, sector and workplace strategies, with the purpose of improving the skills of the South African workforce. Much of the drive behind the development of processes for recognition of prior learning (RPL) emanates from the labour force's need to achieve recognition for learning and skills, attained through work and life experiences. This is very relevant, as these people were prevented from accessing education and training by unjust past education policies and this act is explicit on the need for redress. Statutory bodies were instituted under the Skills Development Act (97 of 1998), with the responsibility to quality assure education and training in designated sectors. Known as Sector Education Training Authorities (SETAs), these bodies have to facilitate development and implementation of RPL processes.

Figure 1: Framework regulating national skills development

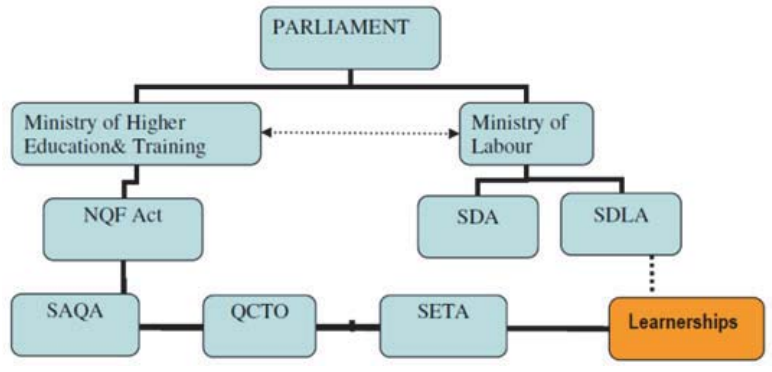

Source: National Skills Development Handbook (2007:174)

While Figure 1 illustrates the framework that regulates national skills development, the objectives of the national skills development initiative are to:

- Achieve major quality improvements within all skills areas and fields of learning

- Optimise the human resources and skills base of the country

- Reform training initiatives and create greater access to learning and accessibility to national qualifications, i.e. formalise all training processes

- Make the business an active learning environment and continually develop the potential of learners (The National Skills Development Handbook 2007:175).

Emanating from the above discussion, the following section will focus on the most pertinent legislation and institutions relating to skills development in South Africa, in order to locate the framework for learnerships, which is part of training SCM officials. SETAs are bodies that are constituted in terms of the Skills Development Act (SDA)(97 of 1998) and generally belong to and oversee skills development for the different economic sectors. For example, there are SETAs for the financial and accounting services sector, public service education and training, and the transport sector. Although established under the law, SETAs exist to serve their economic sector; they are owned by the sector and their boards consist of members from the sector. Responsible for guiding and encouraging quality education and training in the 23 economic sectors of the country, each SETA supports an education and training quality assurance component, which quality assures education and training in their sector. Funded by skills development levies collected in its sector, monies are paid to the SETAs from the National Skills Fund, grants, donations, and income earned for services rendered. According to Erasmus and Van Dyk (2004: 38), some of the main functions of SETAs are developing of a sector skills plan within the framework of the national skills development strategy; implementing its sector skills plan by approving workplace skills plans, allocating grants to employers, education and training providers, and workers; formulating and implementing quality control and evaluation measures for the sector; regular analysis and monitoring of labour markets in their respective sectors; and monitoring education and training in the sector. in Table1.

TheNationalSkillsDevelopmentHandbook2007:115).Anillustrationofthetypeofbeneficiaryandtypesoftrainingis set out 
Table 1: Beneficiary Type and Training Quantity

\begin{tabular}{|l|c|}
\hline Type of Beneficiary & Number trained \\
\hline Employed & 825000 \\
\hline Unemployed & 675000 \\
\hline Unspecified(youth) & 10000 \\
\hline Total & 1510000 \\
\hline
\end{tabular}

Source: The National Skills Development Handbook (2007:115)

The types of training interventions are divided as follows:

Table 2: NSDS2 Minimum Training Targets

\begin{tabular}{|l|c|}
\hline \multicolumn{1}{|c|}{ Types of training } & Number trained \\
\hline Adult basic education and training & 800000 \\
\hline Learning programmes, including learnerships and apprenticeships, but not limited to only these & 700000 \\
\hline New venture creation & 10000 \\
\hline
\end{tabular}

Source: The National Skills Development Handbook (2007:115)

As part of its overall strategy to boost the economic growth rate and halve the unemployment and poverty rate, government in 2004 implemented the Accelerated and Shared Growth Initiative in South Africa (AsgiSA).Consultation with various stakeholders, such as other government departments, labour organisations, organised business, religious leaders, youth organisations, and women in various groupings, as well as forums, together with domestic and international experts, led to this initiative. Over the years, SETAs and the Department of Labour have come under heavy criticism from the media for poor performance issues. Of significance is the sheer volume of resources that passes through the SETA. From2004 to 2005, the 23 SETAs received total resources of R4.5 billion, almost entirely in the form of levy contributions from 193000 employers. Since 2002, about R20 billion has gone through the SETA system. It is safe to say that few stakeholders are convinced that this money has been spent as well as it could have been (The National Skills Development Handbook 2007:118).

South Africa's official opposition party, the Democratic Alliance (DA), called for the scrapping of the SETAs, saying they were a "waste of money", failed to achieve their objective of providing "vocational training", and referred to the SETAs as "financial sinks", into which the South African taxpayer is "pouring millions of rand, for little or no return" (The National Skills Development Handbook 2007:119).As a result, SETA service level regulations were gazetted (Service Level Agreement Regulations, Government Notice No. R. 712, Government Gazette No. 27801), giving the Minister of Labour powers to performance manage SETAs, including identifying areas of poor performance, so that assistance can be provided to remedy the problems.

\section{Public Sector Auditing}

In order to ensure compliance with the above training programmes and to the SCM legislation, compliance enforcement measures are required in the form of a public audit. A public sector audit refers to audits covering the government, healthcare, education, charities, and other public, non-profit organisations, funded by the government(Barrett and O'Connell 2001:124). There are accounting firms that specialise in such public sector audits, not only providing general auditing services, but also other advice such as how effectively these organisations make use of taxpayer money, or how best to manage their financial assets. This audit, generally performed by an accounting firm or the AGSA, is an assessment of an organisation's financial information (Barrett and O'Connell 2001:132). An auditor's aim is to assure that the financial statements issued by an organisation, are free from mistakes and errors. However, unlike audits for private organisations, an auditor, auditing a public organisation, may also go further to assess whether the public organisation is meeting its mission or objectives, and those of the government as a whole(Barrett and O'Connell 2001:139). The public expects that those responsible for handling public money are held fully accountable for the use of public funds. The prime responsibility for ensuring that public money is handled with absolute integrity and spent wisely rests with ministers, elected members, governing bodies, managers, and officials. According to the audit report from the AGSA for the 
2007/2008 financial year, the public audit is an important link in that chain of accountability. Public auditing strengthens accountability, both upwards to the elected or appointed members who provide resources, and outwards to the consumers and beneficiaries, taxpayers, and the wider community at large; according to the Standing Committee on Public Accounts (SCOPA 2008:121).

Generally, there are two types of audits: external and internal. An audit by an outside accounting firm is an external audit. A professional accounting firm, on an annual basis, to check the organisation's compliance to SCM legislation and its financial statements, usually undertakes it. As a rule, the results are disclosed publicly, typically in annual reports or published financial statements. In the United Kingdom (UK), public government agencies are audited in terms of the Budget Responsibility and National Audit Act 2011 of UK, and in the RSA, public institutions are audited by the AGSA. An internal audit is an audit undertaken by the organisation itself, usually on a regular basis by a qualified auditor. The main difference with an external audit is that an internal auditor will report to management or board members instead of making its findings public. In fact, private organisations, or those publicly traded, may have an auditing department that specifically undertakes such internal audits. This is not necessarily the case for public organisations, which in many cases may bring in an audit professional, to undertake an internal audit. Usually, the results of an internal audit are used for internal purposes and to assess issues such as control, governance, and risk management processes within an organisation. Regular internal audits are important, because they will help an organisation keep information up-to-date and keep its checks and balances in place.

A useful resource for public organisations in South Africa is the AGSA, established in terms of the Public Audit Act (25 of 2004). The objective of the AGSA is to provide developmental thinking regarding public audits, and provide consultative and advisory services. It is a good place to find up-to-date information on developments in the public audit segment. For non-governmental public agencies, an external auditor will need to be appointed for an audit. Qualified firms can be determined in terms of the Companies and Intellectual Property Commission (CIPC), which recognises the accounting professions, for the purpose of appointment as accounting officers for auditing, in terms of section 60(4) of the Close Corporations Act (69 of 1984), as amended.

A regular audit is an important way of uncovering irregularities in financial management, whether they are due to outright fraud and corruption or result from negligence in following proper procedures, as per the current legislation, specifically the Public Finance Management Act (1 of 1999), and of establishing public confidence in public money being properly spent. Public audit adds value, not merely by analysing and reporting what has happened after the event, but also by being forward-looking, by identifying lessons to be learnt, and by disseminating good practices. External public auditors thereby have a direct and positive influence on the way organisations and people in the public service discharge their responsibilities. With internal auditors working within public bodies, they help to promote better management and decision making, and thus a more effective use of taxpayer's resources, as well as play an important role in the corporate governance arrangements of public entities (Fox 2010:87). The Public Audit Forum believes that there are three fundamental principles, which underpin public audit:

- the independence of public sector auditors from the organisations being audited

- the wide scope of public audit such as covering the audit of financial statements, regularity, politeness and value for money

- the ability of public auditors to make the results of their audits available to the public and democratically elected representatives.

\section{Conclusion}

It seems appropriate to conclude that learning theories are the guidance in the design, development and implementation of an effective training programme, designed to increase workforce competence, capacity for change, and legislation compliance, as with SCM. This paper also suggests that training and development is one key retention mechanism employed by public institutions to reward and retain employees. In addition, the literature explored shows how different motivational factors influence the extent to which trainees apply that which they have learnt during a training programme, in their workplace. Public sector administration, with its limited resources, was reviewed and found to be a hindrance in service delivery to communities; whereby, service delivery is done through SCM as a public sector mechanism for the procurement of goods, services, and works. In summary, although the literature strongly suggests a direct relationship between job training and employee compliance with SCM legislation, which is done through public auditing, there is little empirical support for this suggestion. Clearly, there is a need to provide such empirical support. 


\section{References}

Adamolekun, L. (1983).Public administration: Nigeria and comparative perspective .London: Longman.

Ahmad, K. Z. \& Bakar, R.A. (2003).The association between training and organizational commitment among white collar workers in Malaysia. International Journal of Training and Development, 7(3), 166-185.

Alberto, P. \&Troutman, A.C. (2003).Applied behavioural analysis for teachers.(6thed). Upper Saddle River, NJ: Merrill, Prentice Hall.

Al-Emadi, M.A. \&Marquardt, M.J. (2007).Relationship between employees beliefs regarding training benefits and organizational commitment in a petroleum company in the state of Qatar. International Journal of Training and Development, 11(1), 49-70.

Antwi, K. B. \& Analoui, F. (2008).Reforming public sector. Facing challenges of effective human resource development policy in Ghana. Journal of Management Development, 27(6), 2008.

Arthur, J. B. (1994).Effects of human resource systems on manufacturing performance and turnover. The Academy of Manufacturing Performance, 37(3), 670-687.

Aryee, S., Budhwar, P.S. and Chen, Z.X. (2002).Trust as a mediator of the relationship between organizational justice and work outcomes: Test of a social exchange model. Journal of Organizational Behavior, 23(3), 267-85.

Auditor-General of South Africa.(2008). Audit report for 2007/2008 financial year.1 ${ }^{\text {st }}$ quarter. South Africa: Auditor-General of South Africa.

Axtell, F. T., \& Maitlis, G. J. (1997).Predicting immediate and longer-term transfer of training.Personnel Review. 26(30), $201-213,30$.

Bandura, A. (1982). Self-efficacy mechanism in human agency.American Psychologist. (37), 122-147.

Barrett, A., \& O'Connell, P. J. (2001). Does training generally work? The returns to in-company training.Industrial Labor Relations Review, 54(3), 647-662.

Bartlett, K. (2001). The relationship between training and organizational commitment: A study in the health care field. Human Resource Development Quarterly, 12 (4), 335-352.

Birdi K. (2010). The taxonomy of training and development outcomes (TOTADO): A new model of training evaluation. Institute of Work Psychology, University of Sheffield. (Paper presented at the Annual BPS Division of Occupational Psychology Conference, 13 $3^{\text {th }}$ $15^{\text {th }}$ January 2010, Brighton, UK.).

Brum, S. (2005). Training and Employee Commitment: What impact does training have on employee commitment and employee turnover. University of Rhode Island.

Brumley, P. (2003).Evaluation of training.London, Chartered Institute of Personnel and Development.

Campbell J. P. and Kuncel N. R. (2001).Individual and team training. In N. Anderson, D. S. Ones, H. K. Sinangil, \& C. Viswesvaran (Eds.), Handbook of Industrial, work and organizational psychology (pp. 278-312). London, England: SAGE.

Carter, M. A. (2005). Improving employee performance through workplace coaching: a practical guide to performance management.(2nd ed). London: Kogan Page.

Cheng, B. S., Jiang, D. Y., \& Riley, J. H. (2003). Organizational Commitment, Supervisory Commitment and Employee Outcomes in the Chinese Context: Proximal Hypothesis or Global Hypothesis? Journal of Organizational Behavior, 24(3), 313-34.

Cheng, E., \&Ho, D. (2001) The influence of job and carrier attitudes on learning motivation and transfer. Carrier Development International. 6(1), 20-27.

Cheng, H., \& Hampson, J. (2008). Transfer of training. A review and new insights. International Journal of management Reviews, 10(4), 327-341.

Chowdhury, M. S. (2006). Human behavior in the context of training: An overview of the role of learning Theories as applied to training and development. Monroe College. Journal of Management Practice, 7(2). [Online] Available: www.tlainc.com/articl112.htm (03 July 2013).

Cloete J.J.N. (1981). Introduction to Public Administration. Pretoria: JL van Schaik Publishers.

Coetzee, M., Botha, J., Kiley, J., \& Truman, K. (2007).Practicing education, training and development in South African organizations. (1st ed). Cape Town: Juta.

Comer, R. J. (2004).Abnormal psychology. (5th ed). New York: Worth Publishers. p. 64.

Cooper, M. C., Lambert, D. M., et al.(1997). Supply chain management: More than a new name for logistics. The International Journal of Logistics Management, 8(1), 1-13.

Coutinho, A. \& Neuman, G. (2008).A model of metacognition, achievement goal orientation, learning style and self-efficacy. Learning Environments Research, II(2), 131-151.

Du Toit, D. F. P., \& Van der Walt, G. (1997).Public management: The grassroots. Kenwyn: Juta Academic.

Erasmus, B. J., \&Van Dyk, P. S. (2004). Training management in South Africa. Oxford: Oxford University Press.

Fox, W. (2010). A guide to public ethics. (2nd ed). Claremont, South Africa: Juta.

Garrow, V. (2004).Training and development and the psychological contract. Training Journal, April: 8-10.

Glance, N. S., Hogg, T., \& Huberman, B. A. (1997).Training and turnover in the evolution of organizations. Organization Science, 8(1), 84-96.

Goldstein, I. L., \& Ford, J. K. (2002).Training in organizations: Need assessment, development, and evaluation.(4th ed).Belmont, CA: Wadsworth.

Holton, E. F., \& Baldwin T.T. (2000). Making transfer happen: An action perceptive on learning transfer systems. Advances in Developing Human Resources. 8, 1-6.

Johanne M. T., R. J. Burke, (1995) "Integrating Diversity And Equality Into The Fabric Of The Organization", Women In Management 
Review, 10(7), 32-39.

Karia N. \& Asaari, H. A. H., (2006).The effects of total quality management practices on employees' work-related attitudes. The TQM Magazine, 18(1), 30-43.

Kirkpatrick, D. L. (1959) Evaluating Training Programs, 2nd ed., San Francisco: Berrett-Koehler.

Kirkpatrick, D. L. (1979).Techniques for evaluating training programs. In D. P. Ely \& P Lomp T. (Eds.), Classic Writings on Instructional Technology (Vol. 1, pp. 231 - 241). Englewood: Libraries Unlimited, Inc.

Kirkpatrick, D. L., \& Kirkpatrick, J. D. (2010). Evaluating training programs.San Francisco: Berrett-Koehler.

Kontoghiorghes, C. (2004). Reconceptualising the learning transfer conceptual framework: Empirical validation of a new systemic model. International Journal of Training and Development, 8(3), 210-221.

Langton, N. \& Robbins, S. (2007). Fundamentals of Organizational Behaviour. Third Canadian Edition.

Liebermann, S. and Hoffmann, S. (2008) 'The impact of practical relevance on training transfer: Evidence from a service quality training program for German bank clerks. International Journal of Training and Development. 12(2): p. 74-86.

Liu M. C. (2002).Learning satisfaction and learning performance of Taipei Elementary School (Unpublished master's thesis), National Taiwan Taipei Normal University, Taiwan.

Mankin, D. (2009). Human resource development. New York: Oxford University Press.

Merilee, S. (1997).Getting good government: capacity building in the public sectors of developing countries. (6thed). [Cambridge, MA]: Harvard Institute for International Development, Harvard University.

Meyer, M. (2007).Managing human resource development-An outcome based approach. (3rd ed). Durban: LexisNexis.

Newman, A., Thanacoody, R., \& Hui, W. (2010). The impact of employee perceptions of training on organizational commitment and turnover intentions: A study of multinationals in the Chinese service sector.A. Nottingham University Business School, Ningbo China b. Middlesex University Business School.

Noe, R., Colquitt, J. A., \& Lepine, J. (2008).Toward an integrative theory of training motivation: A meta-analytic path analysis of 20 years of research. Journal of Applied Psychology, 85(5), 678-707.

Owens, P. L. (2006) One more reason not to cut your training budget: The relationship between training and organizational outcomes. Public Personnel Management, 35(2),163-171.

Pintrich, P. (2000a). An achievement goal theory perspective on issues in motivation terminology, theory, and research. Contemporary Educational Psychology, 25, 92-104.

Pool, L.D., and Sewell, P. (2007). The key to employability: developing a practical model of graduate employability. Education and Training, 49(4), 277-289.

Pugh, K. J., \& Bergin, D. A. (2006). Motivational influences on transfer. Educational Psychologist, 41(3), 147-160.

Republic of South Africa. (1996). The Constitution of the Republic of South Africa, 108 of 1996. Pretoria: Government Printers.

Republic of South Africa. Close Corporations Act, 69 of 1984.Pretoria: Government Printers.

Republic of South Africa.(1998). Skills Development Act, 97of 1998.Pretoria: Government Printers.

Republic of South Africa.(1999). Public Finance Management Act, 1 of 1999.Pretoria: Government Printers.

Republic of South Africa.(2004). Public Audit Act, 25 of 2004.Pretoria: Government Printers.

Republic of South Africa.(2004). Public Audit Act, 25 of 2004.Pretoria: Government Printers.

Republic of South Africa.(2005). Service Level Agreement Regulations. Government Notice No. R. 712 in Government Gazette No. 27801 of 18 July 2005. Pretoria: Government Printers.

Republic of South Africa.(2007).National Skills Development Handbook. Pretoria: Government Printers.

Richard, P. J., Devinney, T. M., Yip, G. S., and Johnson, G. (2009) Measuring Organizational Performance. Towards Methodological Best Practices. Journal of Management, 35(3), 718-804.

Ringquist, Evan, ed. N. D. (2013). Meta-Analysis for Public Management and Policy. New York: Wiley/Josey-Bass.

Rowden, R. W., \& Shamsuddin, A. (2000). The relationship between workplace learning and job satisfaction in small to midsize business in Malaysia. Human Resource Development, 3, 307-322.

Rowden, R. W., and Conine, C. T. (2005) The impact of workplace learning on job satisfaction in small US commercial banks. Journal of Workplace Learning, 17, 216-230.

Sahinidis, A. G. and BourisJ. (2008), Employee perceived training effectiveness relationship to employee attitudes. Journal of European Industrial Training (Emerald Publishing Group), Volume 32(1), 63-76.

Scholl, R. W. (1981). Differentiating organizational commitment from expectancy as a motivating force. Academy of Management Review, 6(4), 589-599.

Schwella, E., Burger, J., Fox, W., \&Muller, J. J. (1996). Public resource management. Kenwyn: Juta\&Co.

SCOPA, (2008).First quarterly report to parliament. [Online] Available: www.parliament.gov.zaParliamentary Communication Services, (29 August 2013).

Settoon, R. P., Bennett, N., \&Liden, R. C. (1996). Social exchange in organizations: Perceived organizational support, leader-member exchange, and employee reciprocity. Journal of Applied Psychology, 81, 219-227.

Shah, A. (2005).Public service delivery. (9th ed). Washington, DC: The World Bank.

Sitzmann, T., Brown, K. G., Casper, W. J., Ely, K., \& Zimmerman, R. D. (2008).A review and meta-analysis of the nomological network of trainee reactions. Journal of Applied Psychology, 93, 280-295.

Skinner, B. F. (1968). The technology of teaching. New York: Appleton-Century-Crofts.

Thornhill C, van Dijk HG: (2010). Public Administration theory: Justification for conceptualisation. Journal of Public Administration, 45 
(1.1) / Jun, pp 95-110.

Truitt, L. D. (2011). The effect of training and development on employee attitude as it relates to training and work proficiency. Salisbury University, [Online] http://www.sgo.sagepub.com/search (29 August 2013).

Wang C. H. (2001). Learning behavior, learning satisfaction, and learning performance in internet class.(Unpublished master's thesis).Da-Ye University. Taiwan.

Wang, Y. (2008). Emotional bonds with Supervisors and Co-Workers: Relationship to Organizational Commitment in China's ForeignInvested Companies. International Journal of Human Resource Management, 19(5), 916-931.

Williams, J. (2007). Hr practices, organizational climate and employee outcomes: Evaluating social exchange relationships in local government. International Journal of Human Resource Management, 18(9), 1627-1647.

World Bank, (2000).Reforming Public Institutions and strengthening Governance: A World Bank strategy. Washington, DC: World Bank. Wright, P. M., Gardner, T. M., Moyndian, L. M., \& Allen, M. R. (2003). The relationship between HR practices and firm performance: Examining causal order. Personnel Psychology, 58, 409-446 [Online] Available: www.managementhelp.org (31 August 2013).

\section{Appendix A}

\section{The taxonomy of training and development outcomes (TOTADO) framework}

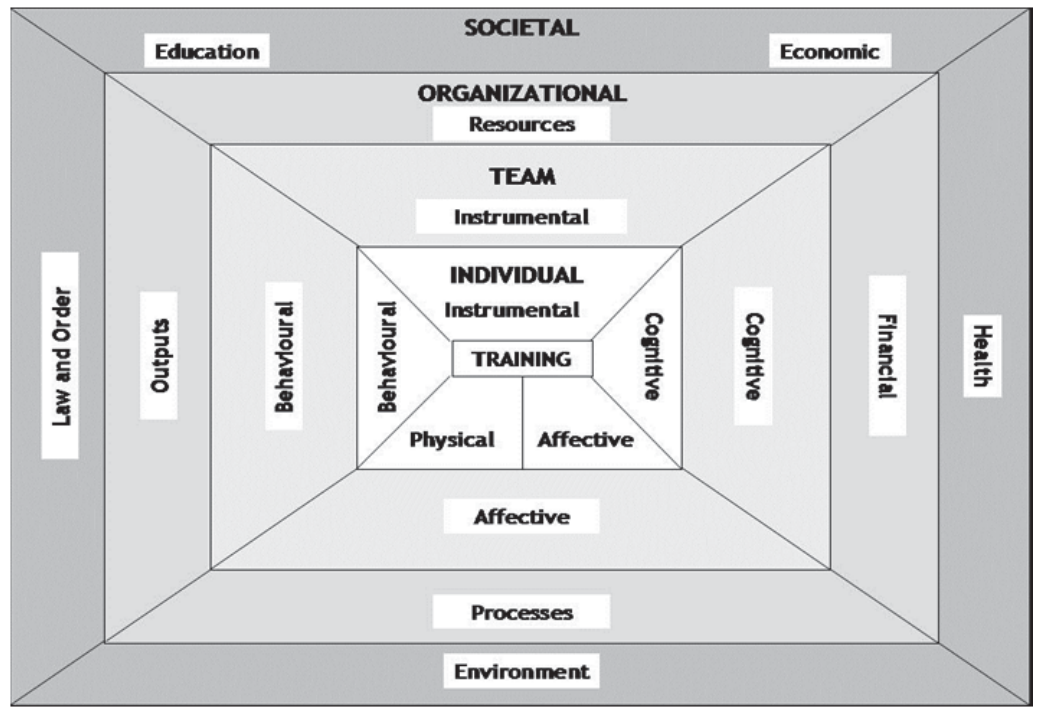

Source: Birdi (2010) 